$\underline{\text { Yuli Astini, Rusdi, E RA Hannah S.: Pengawasan, Kesadaran Retribusi ... }}$

\title{
PENGAWASAN, KESADARAN RETRIBUSI SERTA SARANA DAN PRASARANA SEBAGAI PENYEBAB TIDAK TERCAPAINYA TARGET PENERIMAAN RETRIBUSI PELAYANAN SAMPAH DI KABUPATEN LOMBOK BARAT
}

\author{
Yuli Astini, Rusdi, RA Hannah Syabaneva \\ Sekolah Tinggi Ilmu Ekonomi AMM Mataram
}

\begin{abstract}
The average earning of garbage disposal service retribution by West Lombok Regency's Office of City Planning, Gardening and Sanitation during the period of 2010-2014 was only 40\% of the target in amount. This lower level of earning had prevented the Office from providing optimum services and caused it to be dependent on the Regency Government's subsidies. Ten employees of the Office and one retribution payer were selected as interviewees/informants through a purposive sampling technique, and the data taken from the interviews and from other documents were analyzed in a series of data reduction, display, and verification. The conclusion of this study provides an illustration on how the failure to achieve the targeted amount of revenue was caused by the lack of control in the part of the supervising levy collectors, the low awareness in the part of the community that prevented them from participating in the garbage disposal management and paying the retribution, and the inadequate availability of supporting infrastructure and facilities vis-a-vis the huge amount of garbage dumped every day by the city's population.
\end{abstract}

Keywords : Control of retribution collection, Awareness of retribution payers, Infrastructure and facilities targeted earning of garbage retribution, West Lombok Regency

\section{PENDAHULUAN}

Kabupaten Lombok Barat sebagai salah satu bagian dari pemerintahan daerah di Nusa Tenggara Barat (NTB) memiliki gambaran komposisi PAD tahun 2015 dan 2016 sebagai berikut. 


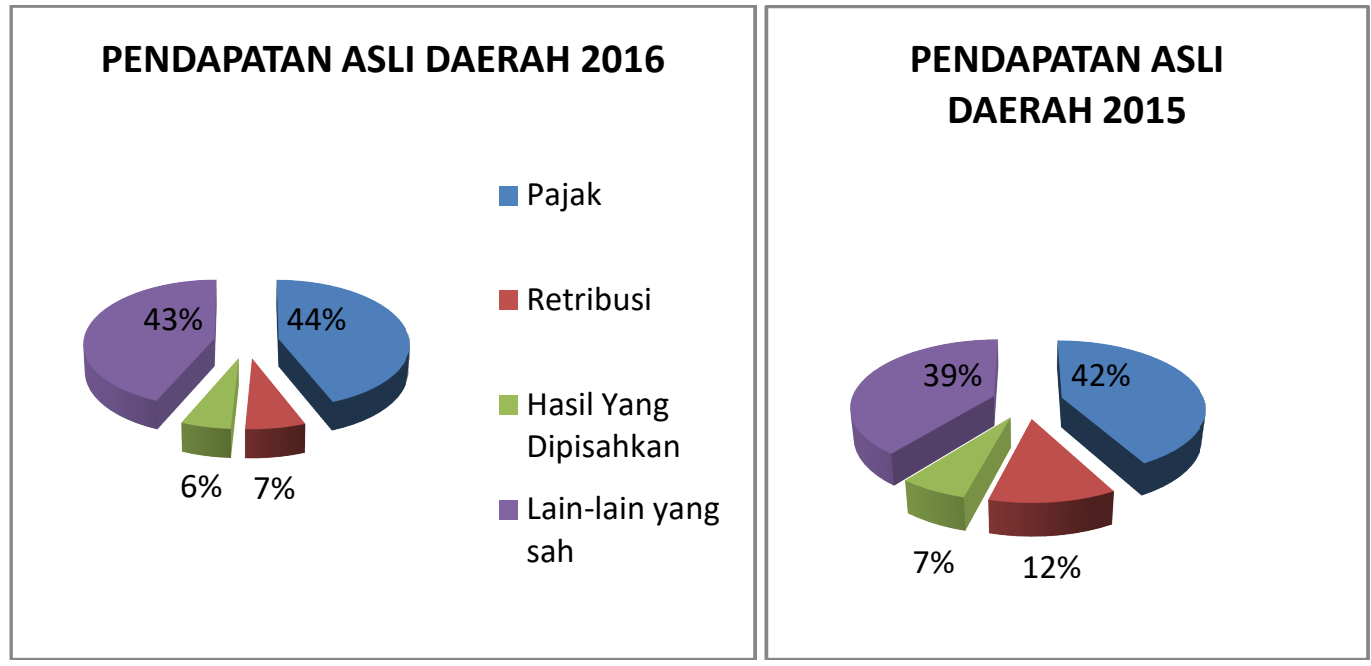

Sumber : Badan Pusat Statistik Lombok Barat (2017)

Berdasarkan Data BPS (2017) kabupaten Lombok Barat menunjukkan adanya penurunan kontribusi retribusi yang cukup signifikan jika dibandingkan dengan kontribusi lainnya, yaitu hampir mencapai $60 \%$. Besarnya persentase penurunan retribusi tersebut merupakan gambaran dari penurunan kontribusi berbagai objek retribusi di Kabupaten Lombok Barat, diantaranya dari retribusi pelayanan persampahan/kebersihan.

Penurunan kontribusi retribusi bukan tanpa alasan, bisa disebabkan karena retribusi dari pelayanan persampahan/kebersihan. Hal tersebut dibuktikan dengan tidak tercapainya target penerimaan retribusi pelayanan sampah pada Dinas Tata Kota, Pertamanan dan Kebersihan Kabupaten Lombok Barat Tahun 2010-2014. Selama empat tahun berturut-turut tidak tercapainya target penerimaan retribusi sampah dari masyarakat KabupatenLombok Baratrata-rata mencapai $40 \%$ setiap tahunnya. Rendahnya penerimaan retribusi sampah dari masyarakat membuat Dinas Kebersihan selaku lembaga pengelola persampahan di Kabupaten Lombok Barat tidak dapat memberikan pelayanan optimal dan selalu bergantung kepada subsidi yang diberikan oleh Pemerintah Kabupaten Lombok Barat.

Menurunnya penerimaan retribusi pelayanan sampah dipengaruhi oleh faktor-faktor seperti ketidakbersediaan masyarakat membayar pelayanan sampah dikarenakan pengelolaan pelayanan sampah yang tidak memuaskan (Susanto dan Rahardyan, 2016) dan ketidakefisienan pemungutan retribusi pelayanan sampah (Yasniva, dkk, 2014). Dari hasil penelitian tersebut dapat disimpulkan bahwa menurunnya penerimaan retribusi pelayanan sampah dikarenakan tidak efektif dan efisiennya pengelolaan pemungutan retribusi pelayanan sampah. 
$\underline{\text { Yuli Astini, Rusdi, E RA Hannah S.: Pengawasan, Kesadaran Retribusi ... }}$

Rahmatullah (2016), dalam penelitiannya menemukan bahwa kurang meratanya sarana dan persarana persampahan yang menyebabkan tidak efektifnya pemungutan retribusi sampah untuk mencapai target serta menjelaskan bahwa pemungutan retribusi pelayanan sampah yang efektif dan efisien dapat dilakukan dengan memaksimalkan perencanaan, pengorganisasian, pengarahan, serta pengawasan langsung kepada masyarakat atas iuran retribusi tersebut. Pengawasan langsung kepada masyarakat tentunya akan menambah pegawai untuk memaksimalkan pengawasan tersebut. Pernyataan ini didukung oleh Sundari, dkk (2014) menyatakan bahwa salah satu faktor penyebab tidak tercapainya target penerimaan retribusi adalah kurangnya pegawai bagian pengawasan.

Selain dari faktor internal yang dihadapi dalam pencapaian target penerimaan retribusi, disisi lain juga ditemukan faktor eksternal yaitu pengguna (user). Susanto dan Rahardyan (2016) menemukan bahwa meskipun masyarakat mampu untuk membayar iuran retribusi, tetapi kesediaan membayarnya masih kurang atau kesadaran dalam membayar iuran retribusi masih kurang disebabkan karena pelayanan pengelolaan sampah tidak memuaskan.

Variabel-variabel seperti pengawasan, kesadaran retribusi, dan sarana dan prasarana yang mempengaruhi tidak tercapainya target penerimaan retribusi tersebut justru berbanding terbalik dengan hasil penelitian yang dilakukan oleh Yoda (2014), dalam penelitiannya menjelaskan bahwa variabel pengawasan, kesadaran retribusi, serta sarana dan prasarana tidak berpengaruh positif terhadap rendahnya penerimaan retribusi.

Perbedaan hasil penelitian atas pengujian rendahnya penerimaan retribusi menggunakan variabel pengawasan, kesadaran retribusi, serta sarana dan prasarana menjadikan alasan penulis untuk melakukan pengujian kembali ketiga variabel tersebut terhadap tidak tercapainya target retribusi penerimaan pelayanan sampah di Kabupaten Lombok Barat.

\section{Pendapatan Asli Daerah}

\section{KAJIAN PUSTAKA}

Berdasarkan Undang-Undang No. 33 Tahun 2004 tentang Perimbangan Keuangan Antara Pemerintah Pusat dan Daerah, Pendapatan Asli Daerah (PAD) adalah pendapatan yang diperoleh daerah dan dipungut berdasarkan peraturan daerah sesuai dengan peraturan perundangundangan, meliputi pajak daerah, retribusi daerah, hasil pengelolaan kekayaan daerah yang dipisahkan, dan lain-lain Pendapatan Asli Daerah (PAD) yang sah. Undang Undang No 23 Tahun 2014 tentang Pemerintah Daerah menjelaskan komponen terpenting dari PAD yaitu: 
a. Hasil PajakDaerah

b. Hasil Retribusi Daerah

c. Hasil Perusahaan Milik Daerah

d. Lain-lain Pendapatan Asli Daerah yang Sah

Tujuan dari PAD disebutkan dalam Pasal 3 Undang-Undang No. 33 Tahun 2004 yaitu memberikan kewenangan kepada Pemerintah Daerah untuk mendanai pelaksanaan otonomi daerah sesuai dengan potensi daerah sebagai perwujudan desentralisasi.

\section{Retribusi Daerah}

Berdasarkan Undang-Undang Nomor 28 Tahun 2009 tentang Pajak Daerah dan Retribusi Daerah, yang selanjutnya disebut Retribusi adalah pungutan daerah sebagai pembayaraan atas jasa atau pemberian izin tertentu yang khusus disediakan dan atau diberikan oleh pemerintah daerah untuk kepentingan orang pribadi atau badan.

Kesimpulan dari pengertian di atas, maka dapat disimpulkan ciri-ciri pokok Retribusi Daerah yaitu:

1. Retribusi adalah pungutan daerah atas penyedian jasa nyata dan langsung kepada yangberkepentingan.

2. Retribusi dipungut olehdaerah

3. Dalam pemungutan retribusi terdapat potensi yang diberikan daerah yang langsung dapatditunjuk.

4. Retribusi dikenakan kepada siapa saja yang memanfaatkan jasa yang disediakan olehdaerah.

Berdasarkan pemaparan di atas, maka penulis menarik kesimpulan bahwa retribusi daerah dipungut karena adanya suatu balas jasa yang dapat disediakan oleh pemerintah daerah. Retribusi beda halnya dengan pajak yang tidak dapat dihindari oleh masyarakat, artinya masyarakat dapat menolak tidak membayar retribusi dengan tidak mengambil manfaat terhadap jasa yang disediakan pemerintah.

\section{Jenis-Jenis Retribusi Daerah}

Sesuai dengan Undang-Undang Nomor 28 Tahun 2009 tentang Pajak Daerah dan Retribusi Daerah pasal 108 ayat 1 dijelaskan bahwa retribusi daerah dibagi atas tiga golongan sebagaimana disebut dibawah ini:

a. Retribusi Jasa Umum yaitu retribusi atau jasa yang disediakan atau diberikan oleh pemerintah daerah untuk tujuan kepentingan dan kemanfaatan umum serta dapat dinikmati oleh orang pribadi atau badan. Jenis-jenis Retribusi Jasa Umum terdiri dari:

1. Retribusi Pelayanan Kesehatan; 
$\underline{\text { Yuli Astini, Rusdi, E RA Hannah S.: Pengawasan, Kesadaran Retribusi ... }}$

2. Retribusi Pelayanan Persampahan/Kebersihan;

3. Retribusi Penggantian Biaya Cetak Kartu Tanda Penduduk dan Akta Catatan Sipil;

4. Retribusi Pelayanan Pemakaman dan Pengabuan Mayat;

5. Retribusi Pelayanan Parkir di Tepi Jalan Umum;

6. Retribusi Pelayanan Pasar;

7. Retribusi Pengujian Kendaraan Bermotor;

8. Retribusi Pemeriksaan Alat Pemadam Kebakaran;

9. Retribusi Penggantian Biaya Cetak Peta;

10. Retribusi Penyediaan dan/atau Penyedotan Kakus;

11. Retribusi Pengolahan Limbah Cair;

12. Retribusi Pelayanan Tera/Tera Ulang;

13. Retribusi Pelayanan Pendidikan; dan

14. Retribusi Pengendalian Menara Telekomunikasi

b. Retribusi Jasa Usaha yaitu retribusi atau jasa yang disediakan oleh pemerintah daerah dengan menganut prinsip komersial karena pada dasarnya dapat pula disediakan oleh sektor swasta. Jenis-jenis Retribusi Jasa Usaha terdiridari:

1. Retribusi Pemakaian Kekayaan Daerah;

2. Retribusi Pasar Grosir dan/atau Pertokoan;

3. Retribusi Tempat Pelelangan;

4. Retribusi Terminal;

5. Retribusi Tempat Khusus Parkir;

6. Retribusi Tempat Penginapan/Pesanggrahan/Villa;

7. Retribusi Rumah Potong Hewan;

8. Retribusi Pelayanan Kepelabuhanan;

9. Retribusi Tempat Rekreasi dan Olahraga;

10. Retribusi Penyeberangan di Air; dan

11. Retribusi Penjualan Produksi Usaha Daerah.

c. Retribusi Perizinan Tertentu yaitu retribusi atau kegiatan tertentu pemerintah daerah dalam rangka pemberian izin kepada orang pribadi atau badan yang dimaksudkan untuk pembinaan, pengaturan pengendalian dan pengawasan atas kegiatan pemanfaatan ruang, penggunaan sumber daya alam, barang, prasarana, saranaatau fasilitas tertentu guna melindungi kepentingan umum dan menjaga kelestarian lingkungan. Jenis-jenis Retribusi Perizinan Tertentu terdiri dari:

1. Retribusi Izin Mendirikan Bangunan;

2. Retribusi Izin Tempat Penjualan Minuman Beralkohol;

3. Retribusi Izin Gangguan;

4. Retribusi Izin Trayek; dan 
5. Retribusi Izin Usaha Perikanan.

Golongan atau jenis-jenis retribusi jasa umum, retribusi jasa usaha dan retribusi perizinan tertentu ditetapkan oleh peraturan pemerintah berdasarkan kriteria tertentu. Penetapan jenis-jenis retribusi jasa umum dan retribusi jasa usaha dengan peraturan pemerintah dengan tujuan agar ketertiban dalam penerapannya dapat memberikan kepastian bagi masyarakat dan disesuaikan dengan kebutuhan nyata daerah yang bersangkutan

\section{Pemungutan Retribusi Pelayanan Persampahan/Kebersihan}

Sesuai dengan Peraturan Daerah Kabupaten Lombok Barat Nomor 3 Tahun 2011 tentang Retribusi Jasa Umumdijelaskan bahwa objek retribusi pelayanan persampahan/kebersihan adalah pelayanan persampahan/kebersihan yang diselenggarakan oleh Pemerintah Daerah, meliputi :

a. pengangkutan sampah yang ada di tempat pembuangan sementara ketempat pembuangan akhir sampah;

b. penyediaan tenaga persampahan/kebersihan;

c. penyediaan sarana dan prasarana pengelolaan persampahan/kebersihan.

Sehubungan dengan peraturan daerah Kabupaten Lombok Barat Nomor 3 Tahun 2011 tentang Retribusi Jasa Umum, Retribusi Pelayanan Persampahan/Kebersihan merupakan Retribusi Pelayanan Persampahan/Kebersihan dipungut sebagai pembayaran atas jasa pelayanan persampahan/kebersihan yang diselenggarakan oleh Pemerintah Daerah. Pengelolaan retribusi Pelayanan Persampahan/Kebersihan sangat diperlukan dalam memanfaatkan potensi yang ada sehingga dapat menjadi sumber pembiayaan yang dapat menunjang penyelenggaraan pemerintah dan pembangunan di daerah. Retribusi Pelayanan Persampahan/Kebersihan merupakan pungutan daerah sebagai pembayaran atas fasilitas yang diberikan kepada umum di dalam pelayanan persampahan

Berdasarkan pemaparan di atas penulis menarik kesimpulan bahwa pemungutan retribusi Pelayanan Persampahan/Kebersihan dilakukan oleh Dinas Tata Kota, Pertamanan dan Kebersihan Kabupaten Lombok Barat yang diberi kewenangan untuk mengatur dan mengelola pemungutan retribusi pelayanan persampahan/kebersihan juga merupakan sumber potensi besar dalam memberikan masukan kas kepada daerah. 
$\underline{\text { Yuli Astini, Rusdi, E RA Hannah S.: Pengawasan, Kesadaran Retribusi ... }}$

\section{Tata Cara Pemungutan Retribusi Pelayanan}

\section{Persampahan/Kebersihan}

Berdasarkan Peraturan Daerah Kabupaten Lombok Barat Nomor 3

Tahun 2011 tentang Retribusi Jasa Umum dalam tata cara pemungutan retribusi pelayanan persampahan/kebersihan dibagi dua :

a. Pembayaran retribusi yang terutang harus dilunasi sekaligus

b. Retribusi dipungut dengan menggunakan Surat Ketetapan Retribusi Daerah (SKRD) atau dokumen lain yang dipersamakan

C. Retribusi yang diutang dilunasi selambat-lambatnya $1 \times 24$ jam hari sejak diterbitkannya SKRD atau dokumen lain yang dipersamakan.

d. Seluruh hasil pungutan retribusi disetor ke kas daerah selambatlambatnya dalam jangka waktu 1 × 24 jam

e. Dalam hal wajib retribusi tertentu tidak membayar tepat pada waktunya atau kurang bayar, dikenakan sanksi administrasi berupa bunga 2\% (dua persen) setiap bulan dari retribusi yang terutang yang tidak atau kurang bayar

Tata cara pembayaran retribusi termasuk penentuan pembayaran, tempat pembayaran, angsuran dan penundaan pembayaran diatur lebih lanjut dengan peraturan bupati.

\section{METODE PENELITIAN}

Jenis penelitian yang digunakan dalam penelitian ini adalah penelitian deskriptif kualitatif. Penelitian ini bertujuan untuk membuat deskripsi, gambaran atau lukisan secara sistematis dan akurat mengenai fakta-fakta, sifat-sifat serta hubungan antar fenomena yang diteliti.

Teknik pengumpulan data yang digunakan dalam penelitian ini adalah:

1. Wawancara

Peneliti menggunakan pedoman wawancara tidak terstruktur yaitu pedoman wawancara yang hanya memuat garis besar yang akan ditanyakan. Peneliti melakukan wawancara dengan pegawai Dinas Tata Kota, Pertamanan dan Kebersihan Kabupaten Lombok Barat dan salah satu masyarakat wajib retribusi.

2. Dokumentasi

Dokumen yang digunakan dalam penelitian ini adalah Profil Dinas Tata Kota, Pertamanan dan Kebersihan Kabupaten Lombok Barat, dan Kabupaten Lombok Barat dalam angka 2016 dan 2015.

Populasi pada penelitian ini adalah seluruh pegawai Dinas Tata Kota, Pertamanan dan Kebersihan Kabupaten Lombok Barat yang berjumlah 128 orang. Sampel dalam penelitian ini adalah 10 orang pegawai Bidang 
Kebersihan pada Dinas Tata Kota, Pertamanan dan Kebersihan Kabupaten Lombok Barat dan 1 orang masyarakat wajib retribusi. Teknik pengambilan sampel yang digunakan adalah purposive sampling. Teknik purposive sampling adalah teknik pengambilan sampel dengan mempertimbangkan beberapa kriteria yang diperlukan seperti berikut ini:

1. Pegawai yang berada dilingkup Dinas Tata Kota, Pertamanan dan Kebersihan Kabupaten Lombok Barat

2. Pegawai yang berada di Bidang Kebersihan Dinas Tata Kota, Pertamanan dan Kebersihan Kabupaten Lombok Barat

3. Petugas pemungut, pengawas dan atasan langsung yang berhubungan dengan Kebersihan dan Retribusi Pelayanan Persampahan/Kebersihan

Adapun teknik analisis data yang digunakan dalam penelitian ini adalah sebagai berikut:

a. Reduksidata

Reduksi dataialah sebagai proses pemilihan, pemusatan perhatian pada penyederhanaan, pengabstrakan dan transformasi data yang kasar yang muncul dari catatan-catatan yang tertulis di lapangan. Reduksi databertujuan untuk mempermudah pemahaman terhadap data yang telah terkumpul dari hasil catatan dilapangan dengan cara merangkum dan mengklarifikasikan sesuai masalah dan aspek-aspek permasalahan yang diteliti.

b. DisplayData

Display datayaitu sekumpulan informasi yang akan memberikan gambaran penelitian secara menyeluruh. Penyajian data yang disusun secara singkat, jelas, terperinci dan menyeluruh akan lebih memudahkan dalam memahami gambaran terhadap aspek-aspek yang diteliti baik secara keseluruhan maupunglobal.

c. Verifikasidata

Verifikasimerupakan tahap terakhir dalam menganalisis data. Data diuji keabsahannya melalui validitas internal yaitu aspek kebenaran, validitas eksternal yaitu penerapan, reliabilitas yaitu konsistensi dan obyektifitas. Data yang sudah teruji kemudian dapat ditarik kesimpulan. Kesimpulan merupakan tahap mencari arti, makna dan menjelaskan yang disusun secara singkat agar mudah dipahami sesuai tujuan penelitian. 
$\underline{\text { Yuli Astini, Rusdi, E RA Hannah S.: Pengawasan, Kesadaran Retribusi ... }}$

\section{HASIL PENELITIAN DAN PEMBAHASAN}

\section{Gambaran Umum Dinas Tata Kota, Pertamanan, dan Kebersihan Kab. LOBAR}

Dinas Tata Kota, Pertamanan dan Kebersihan Kabupaten Lombok Barat (DTPK) dibentuk berdasarkan Peraturan Daerah Kabupaten Lombok Barat Nomor 9 Tahun 2011 tentang Organisasi Perangkat Daerah (Lembaran Daerah Kabupaten Lombok Barat Tahun 2011 Nomor 9) dan Peraturan Bupati Lombok Barat Nomor 36 Tahun 2011 tentang Rincian Tugas, Fungsi dan Tata Kerja Dinas Tata Kota, Pertamanan dan Kebersihan Kabupaten Lombok Barat. DTPK merupakan unsur pendukung tugas kepala daerah, dipimpin oleh Kepala Dinas yang berkedudukan di bawah dan bertanggung jawab kepada Bupati melalui Sekretaris Daerah, dengan tugas melaksanakan penyusunan dan pelaksanaan kebijakan daerah yang bersifat spesifik di bidang tata kota, pertamanan dan kebersihan. DTPK menyelenggarakan fungsi :

1. Penyusunan Rencana Strategis di Bidang Tata Kota, Pertamanan dan Kebersihan;

2. Perumusan Kebijakan Teknis di Bidang Tata Kota, Pertamanan dan Kebersihan;

3. Pemberian dukungan atas penyelenggaraan pemerintahan daerah di Bidang Tata Kota, Pertamanan dan Kebersihan;

4. Pembinaan, Pengendalian, Evaluasi dan Pelaporan Pelaksanaan Kegiatan di Bidang Tata Kota, Pertamanan dan Kebersihan;

5. Pembinaan terhadap Unit Pelaksana Teknis Dinas di Bidang Tata Kota, Pertamanan dan Kebersihan;

6. Pelaksanaan kegiatan Penatausahaan Dinas Tata Kota, Pertamanan dan Kebersihan; dan

7. Pelaksanaan tugas lain yang diberikan oleh Bupati sesuai dengan Tugas Pokok dan Fungsinya.

\section{Pengawasan Pemungutan Retribusi}

Dinas Tata Kota, Pertamanan dan Kebersihan Kabupaten Lombok Barat telah melakukan penghimpunan data objek dan subjek pajak setiap tahunnya dengan cara turun langsung ke objek-objek retribusi sampah. Dimana dengan melakukan pendataan volume sampah, luas objek retribusi dan potensi objek retribusi sampah setiap tahunnya maka dapat diketahui berapa jumlah tarif dan objek retribusi yang masih aktif atau sudah tidak aktif. Sedangkan besarnya tarif retribusi Pelayanan Persampahan/Kebersihan ditetapkan sebesar yang tercantum pada Lampiran II (dua) Peraturan Daerah Kabupaten Lombok Barat Nomor 3 tahun 2011 tentang retribusi jasa umum. 
Namun jika ditinjau dari data objek retribusi Pelayanan Persampahan/Kebersihan di kabupaten Lombok Barat yang terdiri atas kecamatan Batulayar 45 objek, Narmada 4 objek, Lingsar 1 objek, Labuapi 2 objek, Kediri 3 objek, Gunungsari 1 objek, Gerung 3 objek, Kuripan 3 objek, lembar 1 objek dan SKPD 19 objek. Maka masih banyak potensi objek retribusi sampah yang bisa digali lagi. Selanjutnya pemungut retribusi tidak bisa maksimal dalam kegiatan penagihan pajak kepada wajib retribusi karena keterbatasan jumlah petugas. Setiap kecamatan hanya ditempatkan 1 sampai 2 orang petugas. Tentunya hasil tidak bisa optimal apalagi wilayah per kecamatan yang cukup luas dengan jumlah objek retribusi yang cukup banyak.

Petugas pemungut langsung mendatangi objek retribusi dan langsung mengambil iuran retribusi sampah dengan menggunakan Surat Setoran Retribusi Daerah (SSRD). SSRD merupakan bukti pembayaran atau penyetoran retribusi yang telah dilakukan dengan menggunakan formulir atau telah dilakukan dengan cara lain ke kas daerah melalui tempat pembayaran yang ditunjuk oleh Bupati. SSRD di tanda tangani oleh wajib retribusi dan bendahara penerima retribusi. Setelah itu petugas pemungut langsung memberikan uang setoran dan SSRD kepada bendahara penerima retribusi untuk ditanda tangani agar ada bukti bahwa petugas sudah melakukan tugasnya dengan benar, kemudian bendahara penerima retribusi langsung menyetorkan kepada kas daerah.

Selain itu juga dalam menagih retribusi, terkadang wajib retribusi tidak mau membayar dengan alasan karena telat diangkutkan sampahnya oleh petugas kebersihan. Banyak juga wajib retribusi yang marah karena sampahnya jarang diangkut oleh petugas kebersihan sementara itu retribusi selalu dibayarkan dan tidak pernah terlambat. Ada juga wajib retribusi yang terlambat membayar retribusi sampai 2 atau 3 bulan, sehingga petugas memberikan surat teguran terhadap wajib retribusi tersebut. Dan petugas retribusi juga telah menyiapkan surat tugas dari Dinas yang akan ditunjukkan kepada wajib retribusi untuk menghindari pungutan liar.

Penelitian ini sejalan dengan hasil penelitian Sri dkk (2014) bahwa faktor yang menyebabkan tidak tercapainya target penerimaan retribusi pasar disebabkan oleh kurangnya pegawai bagian pengawasan, belum efektifnya pemberlakuan sanksi, adanya pungutan liar. Riyadhi (2016) juga menyimpulkan bahwa faktor-faktor yang menghambat tidak tercapainya peningkatan penerimaan PBB di Kota Bandar Lampung antara lain karena manajemen sumber daya fiskus PBB yang belum baik akibat dari kurangnya penyuluhan tentang pentingnya pajak bagi pembangunan daerah dan kurangnya pendataan ulang secara berkala di setiap kecamatan. Serta 
$\underline{\text { Yuli Astini, Rusdi, E RA Hannah S.: Pengawasan, Kesadaran Retribusi ... }}$

adanya ketidak patuhan Wajib Pajak yang ditunjukkan dengan tidak tepatnya waktu dalam membayar pajak dan tidak ada pemberitahuan dari WP apabila pindah lokasi. Rahmatullah (2016) juga menyimpulkan faktor penghambat Dinas Kebersihan dan Pertamanan Kota Samarinda dalam meningkatkan pendapatan asli daerah kota samarinda salah satunya mengenai anggaran dana yang tidak mencukupi untuk menambah pegawai pemungut retribusi daerah langsung kepada subjek/objek retribusi.

\section{Kesadaran Wajib Retribusi}

Dinas Tata Kota, Pertamanan dan Kebersihan Kabupaten Lombok Barat telah melakukan sosialisasi tentang persampahan dan Peraturan Daerah kabupaten Lombok Barat nomor 3 tahun 2011 tentang retribusi jasa umum. Sosialisasi ini sudah dilaksanakan disetiap kecamatan serta melalui program osamtu (olah sampah sampai tuntas). Sosialisasi ini bertujuan untuk membangun dan meningkatkan kesadaran masyarakat terhadap sampah dan lingkungannya sendiri, bahwa sampah tidak hanya bisa dibuang begitu saja namun sampah juga bisa menjadi barang yang bisa menghasilkan pendapatan/uang bagi masyarakat. Masyarakat diharapkan bisa mengelola sampahnya sendiri mulai dari hal yang kecil yaitu penanganan sampah dengan memisahkan sampah basah dan sampah kering serta bagaimana mengelola sampah tersebut.

Disamping itu juga, untuk meningkatkan kesadaran masyarakat agar tetap menjaga kebersihan lingkungan, Dinas Tata Kota, Pertamanan dan Kebersihan Kabupaten Lombok Barat mengadakan sosialisasi mengenai persampahan terhadap masyarakat misalnya melibatkan ibu-ibu PKK, BSM (Bank Sampah Masyarakat), serta kepala desa untuk mengadakan program pengolahan sampah terpadu dengan system 3R (Reduce, Reuse,Recycle).

Peran serta masyarakat dalam pegelolaan sampah terbagi dua aspek yaitu aspek aktif dan pasif, aspek aktif itu masyarakat harus turut serta dalam mengolah dan mengelola sampahnya sedangkan aspek pasif, masyarakat diwajibkan membayar retribusi. Namun peran serta masyarakat seperti yang diharapkan masih kurang dan tidak optimal karena masih kurangnya kesadaran sebagian masyarakat akan pentingnya kebersihan sebagai contoh masih ada masyarakat yang tidak membuang sampahnya ke tempat pembuangan sampah (TPS) dan bahkan tidak menyediakan tempat sampah dirumahnya sendiri serta masih ada sebagian masyarakat yang tidak mau membayar iuran sampah. Penelitian ini mendukung hasil penelitian Iwan dan Benno (2016) bahwa nilai rata-rata nilai kesediaan membayar wajib retribusi berada di bawah nilai rata-rata tingkat kemampuan membayar. Hal ini berarti bahwa masyarakat mampu untuk membayar iuran sampah. Pelayanan 
pengelolaan persampahan yang tidak memuaskan menjadi penyebab utama rendahnya penerimaan iuran sampah.

\section{Sarana dan Prasarana}

Salah satu penyebab tidak tercapainya realisasi pemungutan retribusi pelayanan persampahan/kebersihan pada Dinas Tata Kota, Pertamanan dan Kebersihan Kabupaten Lombok Barat adalah sarana dan prasarana yang kurang memadai. Sarana pengolahan sampah yang masih belum memadai khususnya armada pengangkutan sampah yang jumlahnya masih sedikit, kondisi armada yang sering rusak dan masih ada satu mobil yang digunakan oleh dua sopir karena keterbatasan kendaraan operasional persampahan.

Berdasarkan data produksi sampah rata-rata harian tahun 2016 di Kabupaten Lombok Barat, terdapat sebanyak $515.67 \mathrm{~m}^{3}$ sampah per hari yangterdiri dari wilayah pelayanan sebanyak $360.97 \mathrm{~m}^{3}$ dan wilayah non pelayanan sebanyak $154.70 \mathrm{~m}^{3}$ dengan kemampuan/daya angkut sampah sebagai berikut:

Kapasitas masing-masing armada :

- Panther Pickup

- Dumptruck

- Truck Amroll/Container

- Kendaraan Roda 3 (Tiga)

- Kendaraan Roda 2 (Gerobak Dorong)

Daya angkut Armada per hari :241,16 $\mathrm{m}^{3}$

- Panther Pickup (2 bhx2 ritx 3,36m³) : 13,44 $\mathrm{m}^{3}$

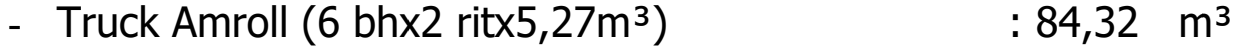

- Dam Truck (8 bhx2 ritx4,68m³) :84,24 $\mathrm{m}^{3}$

- Kendaraan Roda 3 (26bh x 2rit x 1,05 m²) :54,60 $\mathrm{m}^{3}$

- Kendaraan Gerobak Dorong R.2(35bhx2x0,50m³) :35,00 $\mathrm{m}^{3}$

Sedangkan Dinas Tata Kota, Pertamanan dan Kebersihan Kabupaten Lombok Barat hanya memiliki 13 armada pengangkutan sampah. Jika pengangkutan sampah menggunakan pola 2 shift maka jumlah kebutuhan ideal armada sebanyak 32 buah dump truck/Amroll. Karena keterbatasan sarana dan prasarana ini sehingga banyak pelayanan yang tidak maksimal, apalagi dengan jumlah sampah yang terus bertambah tentunya dari segi penanganan melalui sarana dan prasarana masih terbatas juga.

Dalam rangka mengatasi keterbatasan sarana dan prasarana pengolahan sampah, Dinas Tata Kota, Pertamanan dan Kebersihan Kabupaten Lombok Barat telah memprogramkan pengembangan kinerja pengelolaan persampahan melalui penyediaan prasarana dan sarana pengelolaan persampahan, peningkatan operasi dan pemeliharaan prasarana 
$\underline{\text { Yuli Astini, Rusdi, E RA Hannah S.: Pengawasan, Kesadaran Retribusi ... }}$

dan sarana persampahan, pengembangan teknologi pengolahan persampahan, menjalin kerjasama pengelolaan sampah dan pengembangan teknologi/komunikasi persampahan. Hasil penelitian ini sejalan dengan hasil penelitian Rahmatullah (2016) yang menyimpulkan bahwa salah satu faktor penghambat Dinas Kebersihan dan Pertamanan Kota Samarinda dalam meningkatkan pendapatan asli daerah kota samarinda kurang meratanya sarana dan prasarana persampahan disetiap kecamatan yang ada di Kota Samarinda.

\section{KESIMPULAN}

Penyebab tidak tercapainya target pemungutan retribusi pelayanan sampah/kebersihan pada Dinas Tata Kota, Pertamanan dan Kebersihan Kabupaten Lombok Barat adalah pemungutan retribusi pelayanan persampahan/kebersihan yang belum optimal dan kurangnya kesadaran wajib retribusi dalam membayar retribusi pelayanan persampahan/kebersihan serta sarana dan prasarana yang kurang memadai. Oleh karena itu Dinas Tata Kota, Pertamanan dan Kebersihan Kabupaten Lombok Barat perlu menggali lagi potensi objek retribusi pelayanan persampahan/kebersihan dalam rangka meningkatkan penerimaan retribusi, menambah jumlah armada sampah untuk mengatasi permasalahan sampah yang tidak bisa terangkut karena kurangnya armada sampah, menambah jumlah petugas retribusi untuk dapat mengoptimalkan jumlah penerimaan retribusi dan mengadakan sosialisasi pentingnya menjaga kebersihan dan mengelola sampah mulai dari hal yang kecil dengan memisahkan sampah basah dan sampah kering melalui spanduk atau banner di setiap objek retribusi.

\section{DAFTAR PUSTAKA}

Badan Pusat Statistik Kabupaten Lombok Barat. 2017. Kabupaten Lombok Barat Dalam Angka 2016.

Badan Pusat Statistik Kabupaten Lombok Barat. 2016. Kabupaten Lombok Barat Dalam Angka 2015.

Boby Fandhi Putra, Dwi Atmanto, Nila Firdausi Nuzula. 2014. Analisis Efektivitas Penerimaan Dan Kontribusi Retribusi Daerah Terhadap Pendapatan Asli Daerah (Studi Pada Dinas Pengelola Keuangan Daerah Kota Blitar). Jurnal Administrasi Bisnis (JAB) Vol. 10 No. 1 Mei 2014 (http://administrasibisnis.studentjournal.ub.ac.id)

Darwin. 2010. Pajak Daerah Dan Retribusi Daerah. Jakarta: Mitra Wacana Media. 
Dinas Tata Kota, Pertamanan dan Kebersihan Kabupaten Lombok Barat. 2017. Profil Dinas Tata Kota, Pertamanan dan Kebersihan 2016.

Iwan Susanto dan Benno Rahardyan. 2016. Analisis Penerimaan Retribusi Sampah oleh Masyarakat dalam Upaya Peningkatan Pelayanan Pengelolaan Persampahan di Kota Bandung Bagian Timur. Jurnal Perencanaan Wilayah dan Kota. Journal of Regional and City PlanningVol. 27, no. 3, pp. 219-235, December 2016 DOI: 10.5614/jrcp.2016.27.3.4

Peraturan Daerah Kabupaten Lombok Barat Nomor 3 Tahun 2011 Tentang Retribusi Jasa Umum.

Prakorso, Kesit Bambang. 2003. Pajak dan Retribusi Daerah. Yogyakarta: UII Press.

Rahmatullah. 2016. Pengelolaan Retribusi Persampahan/Kebersihan Dalam Meningkatkan Pendapatan Asli Daerah (PAD) Pada Dinas Kebersihan Dan Pertamanan Kota Samarinda. eJournal Administrasi Negara, Vol 4 (4), 2016 : 5023-5033 ISSN 0000-0000, ejournal.an.fisip-unmul.ac.id Riyadhi Adyan Syah. 2016. Faktor-Faktor Penyebab Tidak Tercapainya Penerimaan Pajak Bumi Dan Bangunan (PBB) Di Kota Bandar Lampung. Skripsi Fakultas Ilmu Sosial Dan Ilmu Politik Universitas Lampung.

Sjafrizal. 2008. Ekonomi Regional Teori dan Aplikasi. Padang: Baduose Media. Siahaan, Marihot P. 2013. Pajak Daerah dan Retribusi Daerah. Jakarta: Rajawali Pers.

Sri Sundari, Lili Syafitri, Raisa Pratiwi. 2014. Analisis Faktor-Faktor Penyebab Tidak Tercapainya Target Peneriman Retribusi Pasar Pada Perusahaan Daerah Pasar Palembang Jaya. Artikel ilmiah STIE MDP Palembang.

Undang-Undang Republik Indonesia Nomor 28 Tahun 2009 tentang Pajak Daerah dan Retribusi Daerah.

Undang-Undang Republik Indonesia Nomor 23 Tahun 2014 tentang Pemerintahan Daerah.

Undang-Undang Republik Indonesia Nomor 33 Tahun 2004 tentang Perimbangan Keuangan Antara Pemerintah Pusat dan Daerah. 